\title{
Groundwater compartmentalisation: a water table height and geochemical analysis of the structural controls on the subdivision of a major aquifer, the Sherwood Sandstone, Merseyside, UK
}

\author{
E. A. Mohamed and R. H. Worden \\ Department of Earth and Ocean Sciences, University of Liverpool, 4, Brownlow Street, Liverpool, L69 3GP, UK
}

Received: 19 April 2005 - Published in Hydrology and Earth System Sciences Discussions: 10 June 2005

Revised: 26 October 2005 - Accepted: 3 December 2005 - Published: 8 February 2006

\begin{abstract}
Compartmentalisation, the subdivision of an aquifer into discrete and relatively isolated units, may be of critical importance for the protection of groundwater although it has been largely ignored in the groundwater literature. The Lower Triassic Sherwood Sandstone, in north west of England, UK, may be a good example of an aquifer that has been compartmentalised by numerous high angle faults with displacements of up to $300 \mathrm{~m}$. The study was initiated to assess the local groundwater flow, the extent of seawater invasion and the controls on recharge in the aquifer and to try to understand whether the aquifer is broken into discrete compartments.

Maps and schematic cross-sections of groundwater heads for the years 1993, and 2002 were prepared to trace any structural controls on the groundwater heads across the area. Studying the contour maps and cross sections revealed that: 1) there are substantial differences in groundwater head across some of the NNW-SSE trending faults implying that groundwater flow is strongly limited by faults, 2) an anticline in the east of the area acts as a groundwater divide and 3) the groundwater head seems to follow the topography in some places, although steep changes in groundwater head occur across faults showing that they locally control the groundwater head. The aquifer was thus provisionally subdivided into several hydrogeological sub-basins based on groundwater head patterns and the occurrence of major structural features (faults and a fold).

Using groundwater geochemistry data, contour maps of chloride and sulphate concentration largely support the structural sub-division of the area into hydrogeological subbasins. Scrutiny of groundwater geochemical data, averaged for each sub-basin, confirmed the degree of compartmentalisation and the occurrence of sealed faults. The variation of the geochemical composition of the groundwater not only re-
\end{abstract}

Correspondence to: E. A. Mohamed

(essam@liv.ac.uk) lates to the different, localised geochemical processes and seawater intrusion but also relates to compartmentalisation due to faulting. Faults have limited the degree of mixing between the groundwater types thus retaining the specific characteristics of each sub-basin. Highly localised seawater intrusion is mainly controlled by low permeability fault close to the Irish Sea and Mersey estuary. There is effectively no invasion of seawater beyond the faults that lie closest to the coastline. Freshwater recharge to the aquifer seems to be highly localised and mainly occurs by vertical percolation of rain and surface water rather than whole aquifer-scale groundwater flow. This study provides a detailed understanding of the groundwater flow processes in Liverpool as an example of methods can be applied to groundwater management elsewhere.

\section{Introduction}

Groundwater locally provides more than $75 \%$ of public water supply in the UK and $>35 \%$ in England and Wales as a whole. Protecting groundwater supplies is important in industrialised areas; understanding recharge and how, and in what direction, water moves within an aquifer are important steps in developing long term practical strategies. Therefore, much work has focused on the protection of water supplies by determining the areas contributing recharge to watersupply wells and by specifying regulations to minimize the opportunity for contamination of the recharge water by activities at the land surface (Reilly and Pollock, 1993). A key issue in this study is the degree of aquifer subdivision, known as compartmentalisation, into discrete portions separated by low permeability barriers. Compartmentalisation in aquifers may be a result of faulting where fault zones typically have low permeability due to a combination of cataclasis and entrainment of clay minerals on the fault plane resulting in fault gouge. The thickness and degree of permeability

(C) 2006 Author(s). This work is licensed under a Creative Commons License. 


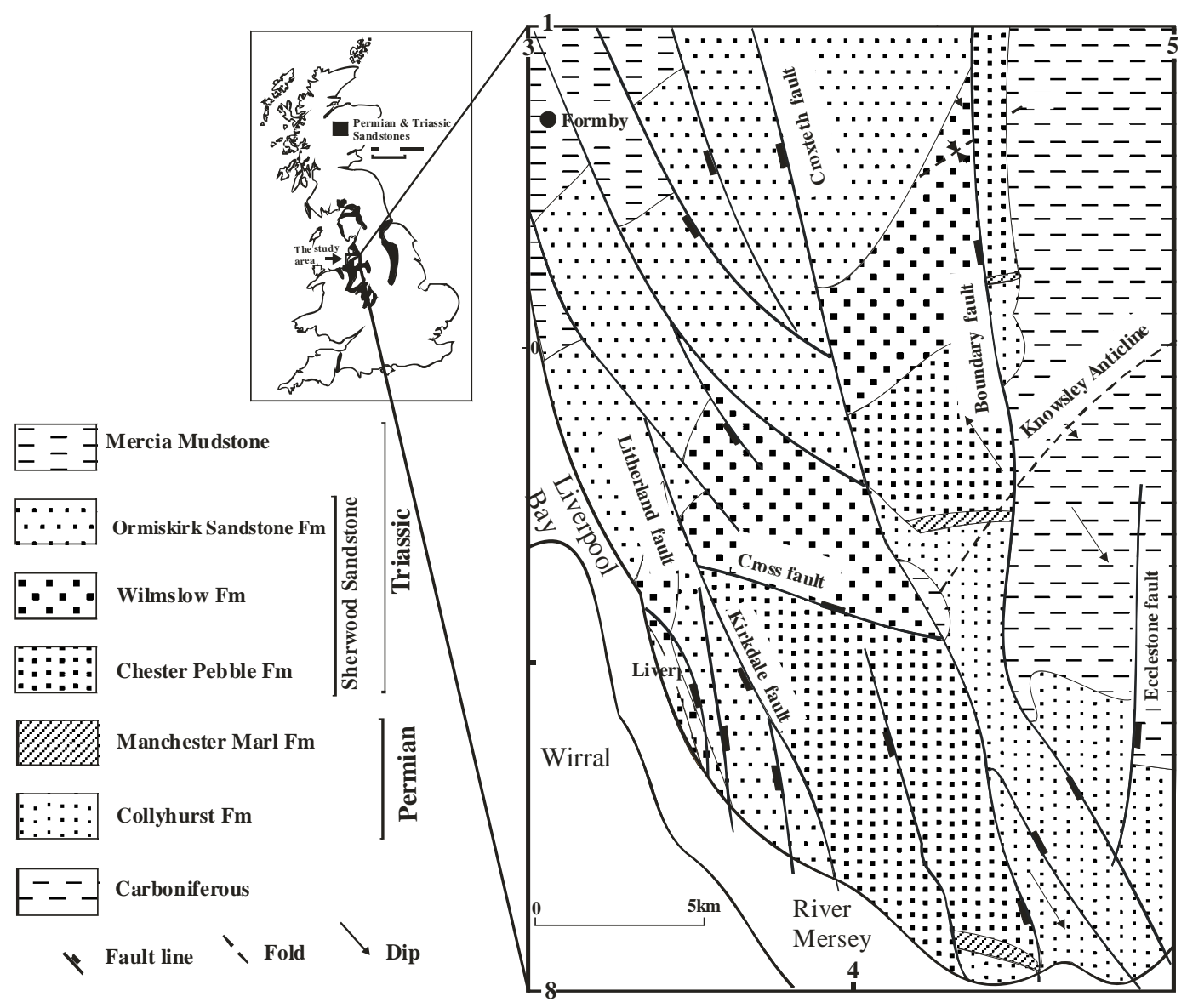

Fig. 1. Maps of hydrogeologically important aspects of the area around Liverpool.

of fault zones tends to increase with the extent of fault displacement. Compartmentalisation is important since it fundamentally controls how different parts of an aquifer are connected and how, and in what direction, groundwater moves within an aquifer.

Compartmentalisation of fluid-bearing porous and permeable rocks has been a subject of great interest in the petroleum industry since understanding the degree of segmentation of oil fields has a major impact on production strategies (e.g. Smalley and England, 1992, 1994; Smalley et al., 1995). Compartmentalisation broadly occurs due to a combination of impermeable faults, interbedded permeable and impermeable rock units, lateral pinch-out of permeable sedimentary units. The degree of oilfield compartmentalisation has been assessed using a combination of structural geology, sedimentology, fluid pressure analysis and fluid geochemical differences (e.g. Smalley and England, 1992, 1994; Smalley et al., 1995). There has been much less attention paid to the occurrence of compartmentalised groundwaterbearing aquifers. While the main driver for the study of compartmentalised petroleum accumulations is the maximisation of profit, the driver for the study of the compartmentalisation of groundwater aquifers is the protection of resources and observance of ever-stricter environmental legislation.

The objective of this study is to apply some of the conceptual approaches adopted by the petroleum industry to assess the degree of compartmentalisation of a locally important aquifer in the UK: the Triassic Sherwood Sandstone. We will assess potential compartments within the aquifer using geological and groundwater head maps and then test these initial ideas using geochemical data. The key scientific questions being addressed are:

1. Is the Sherwood Sandstone (the UK's most important aquifer) a "tank of sand" in the Merseyside area (an implicit assumption in the hydrogeological map of Lewis et al., 1989), or is it split into separate compartments or sub-basins?

2. Is it possible to use groundwater head data and water geochemical data to define separate compartments or sub-basins within an aquifer?

The study area is located in the industrially important and populous north west of England and encompasses the urban area of Liverpool (Fig. 1). The intensively investigated 
Table 1. Regional stratigraphy of the bedrock underlying Liverpool and Greater Merseyside. Adapted from University of Birmingham, 1984 and Tellam, 1994.

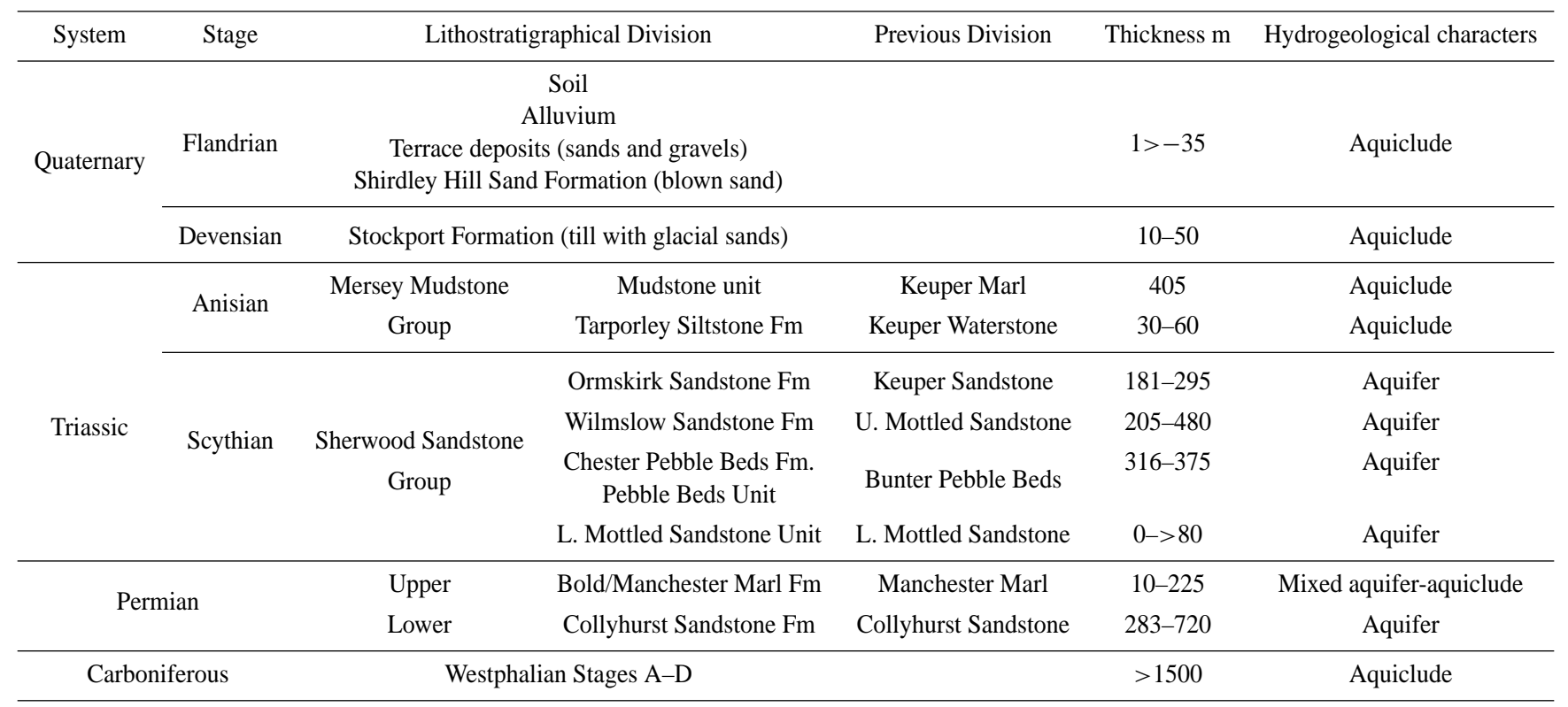

area extends from Widnes to Liverpool and as far north as Formby.

Despite the local and national importance of the Sherwood Sandstone aquifer, few previous studies substantially mentioned the roles of lithology and geological structure as controls on groundwater geochemistry.

The occurrence and movement of groundwater in the district were discussed by Stephenson (1850) including the importance of fissures and the fact that there was a finite amount groundwater. He also recognized the occurrence of seawater intrusion into the aquifer. The role of regional topography as a control on groundwater contours for the Sherwood aquifer (in the east of England) was discussed by Strahan in Hull (1882). Significantly, Morton (1866) discussed the location of wells as a possible control on yield and water quality and concluded that the highest yielding wells were located on faults. In contrast, Moore (1902) examined the porosity across a fault plane in the Sherwood Sandstone aquifer on the adjacent Wirral peninsula, just southwest of the area of interest, and concluded that porosity-reduction occurred across fault planes since they were cemented by calcite and pyrite. Also a porosity-occluding clay-rich fault gouge was found in two zones up to $0.5 \mathrm{~m}$ thick.

The Mersey Railway Tunnel, excavated through the aquifer, connects the Liverpool area to the Wirral (essentially the industrial town of Birkenhead) and it was recorded that abstraction from the tunnel led to deterioration of groundwater quality (Wedd et al., 1923).

The hydrogeology of the Sherwood Sandstone aquifer in the Merseyside and Manchester areas was described in re- ports for the Geological Survey by Taylor (1957) and Land (1964). Both authors presented maps with groundwater contours. The high degree of faulting in the aquifer and its possible importance for internal boundaries occurring within the Permo-Triassic aquifer was noted by University of Birmingham (1981). In an assessment of the saline intrusion into the Sherwood Sandstone aquifer it was suggested that wherever fault movement was small the effect on the transmissivity might be small depending on the nature of the fault zone (University of Birmingham, 1984). Large displacement, however, may juxtapose impermeable strata against permeable strata leading to a significant local reduction of the effective hydraulic conductivity. Just outside of the studied area, the Roaring Meg fault has low permeability and restricts saline groundwater movement (Tellam et al., 1986). However the published synthetic hydrogeological map of the area has groundwater head contours that ignore all faults and has seemingly been drawn on the assumption that the aquifer is not sub-divided into compartments (Lewis et al., 1989). Barker (1996) investigated the geochemistry and isotope of the saline-freshwater mixing zone beneath Liverpool and stated that the change in groundwater chemistry was due to the presence of the fault and implies that it acts as a hydrological barrier to groundwater flow.

The main objectives of this study will be focused on the role of the structural geology of the area explicitly trying to establish the impact of faults on groundwater conditions using records of groundwater head and geochemistry variations over the period 1993 to 2002 . 

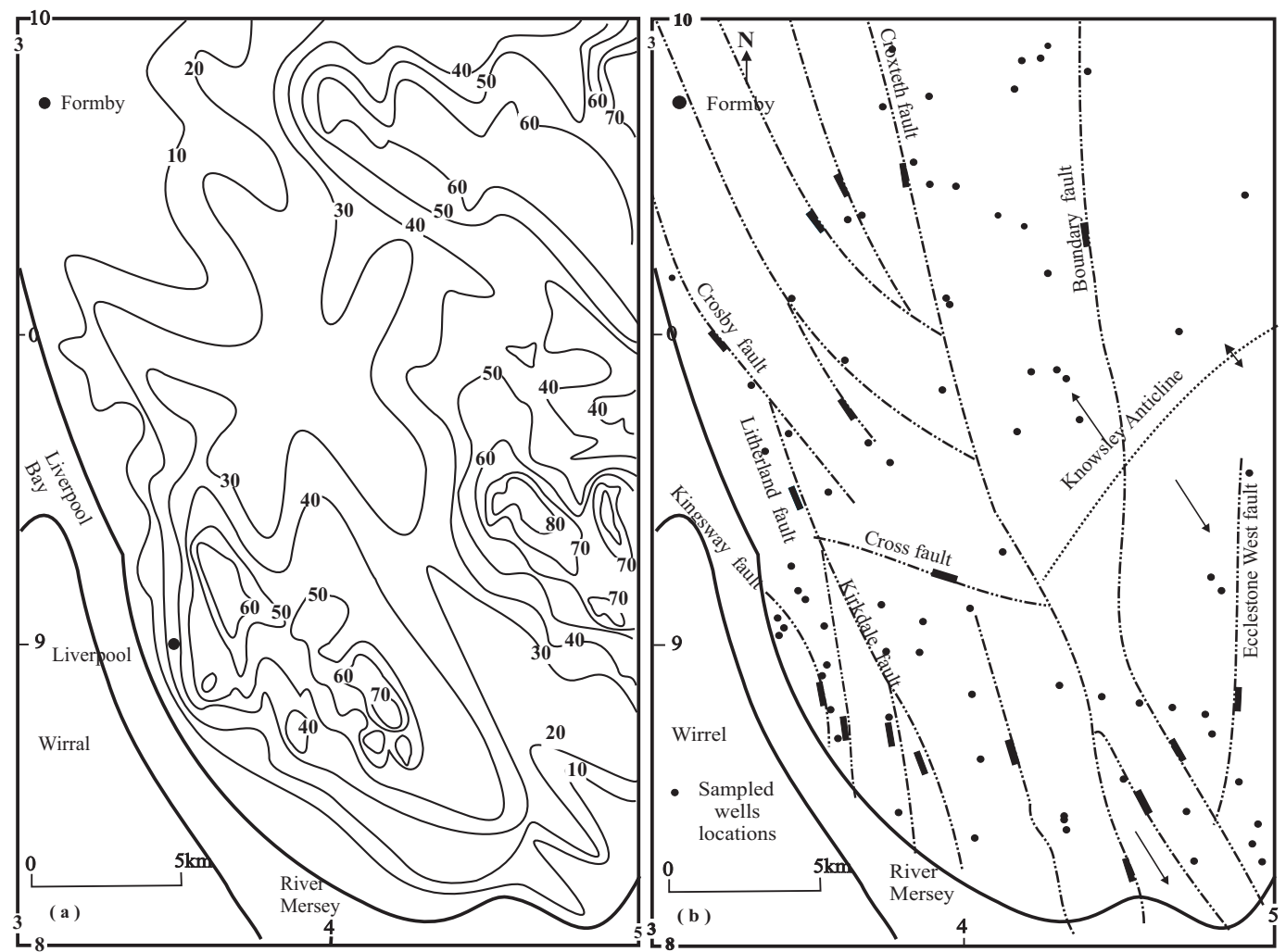

Fig. 2. (a) Topographic map with contours in meters, (b) Distribution of boreholes across the aquifer for which data have been used. Notice the location of faults and the boreholes distribution.

\section{Geology}

\subsection{General geology}

Permo-Triassic sedimentary rocks represent the principle aquifer units in the area. The regional stratigraphy is represented in Table 1 with the regional distribution of rocks at the surface given in Fig. 1. Permo-Triassic sedimentary rocks rest unconformably over Upper Carboniferous wellindurated sandstones and mudstones that are typically considered to denote the low permeability base of the aquifer. These older rock units crop out in the east and north east of the area (Fig. 1).

The Permo-Triassic sedimentary succession starts with the Collyhurst Sandstone Formation, which is red to grey in colour and fine to medium grained. The stratigraphicallyequivalent Manchester Marl and Bold Formations conformably overlie the Collyhurst Sandstones. The Manchester Marl, in the north, is composed of calcareous siltstone or shale with thin bands of fossiliferous limestone, while the Bold Formation, in the south, is made up of fine to very finegrained sandstones.

The major sandstone-dominated unit that represents the bulk of the aquifer in the area, the Sherwood Sandstone Group, overlies the Manchester Marl and Bold Formations. The base of this group is the Chester Pebble Formation. This formation is made up of two units; the Lower Mottled Sandstone Unit, composed of red and brown, fine to medium grained weakly cemented sandstone, followed by the Pebble Beds Unit, composed of red or yellow, cross laminated, coarse to medium grained pebbly sandstones. The overlying Wilmslow Sandstone Formation is characterised by soft, fine-grained sandstones. The Ormskirk Sandstone Formation has two lithological units; a lower one directly overlying the Wilmslow Formation consists of greyish-yellow to red sandstone and upper one composed of medium and fine grained sandstone.

The Upper Triassic Mercia Mudstone Formation, a major argillaceous sequence overlying the Sherwood Sandstone, is considered to be the upper low-permeability boundary of the entire aquifer. It is composed of two units: the lower one being the Tarporly Siltstone and the upper one being the Mercia Mudstone.

The Quaternary system represents a very short length of geological time and is characterised in the area by a restricted depositional thickness, which nevertheless is of hydrogeological significance. Thicknesses of 5 to $10 \mathrm{~m}$ are common, but significant parts of the area are without Quaternary cover (e.g. Liverpool, Kirkby, and Ormskirk; University of Birmingham, 1984). Lithologically, these deposits are dominated by glacial tills and sands followed by well-sorted sands 

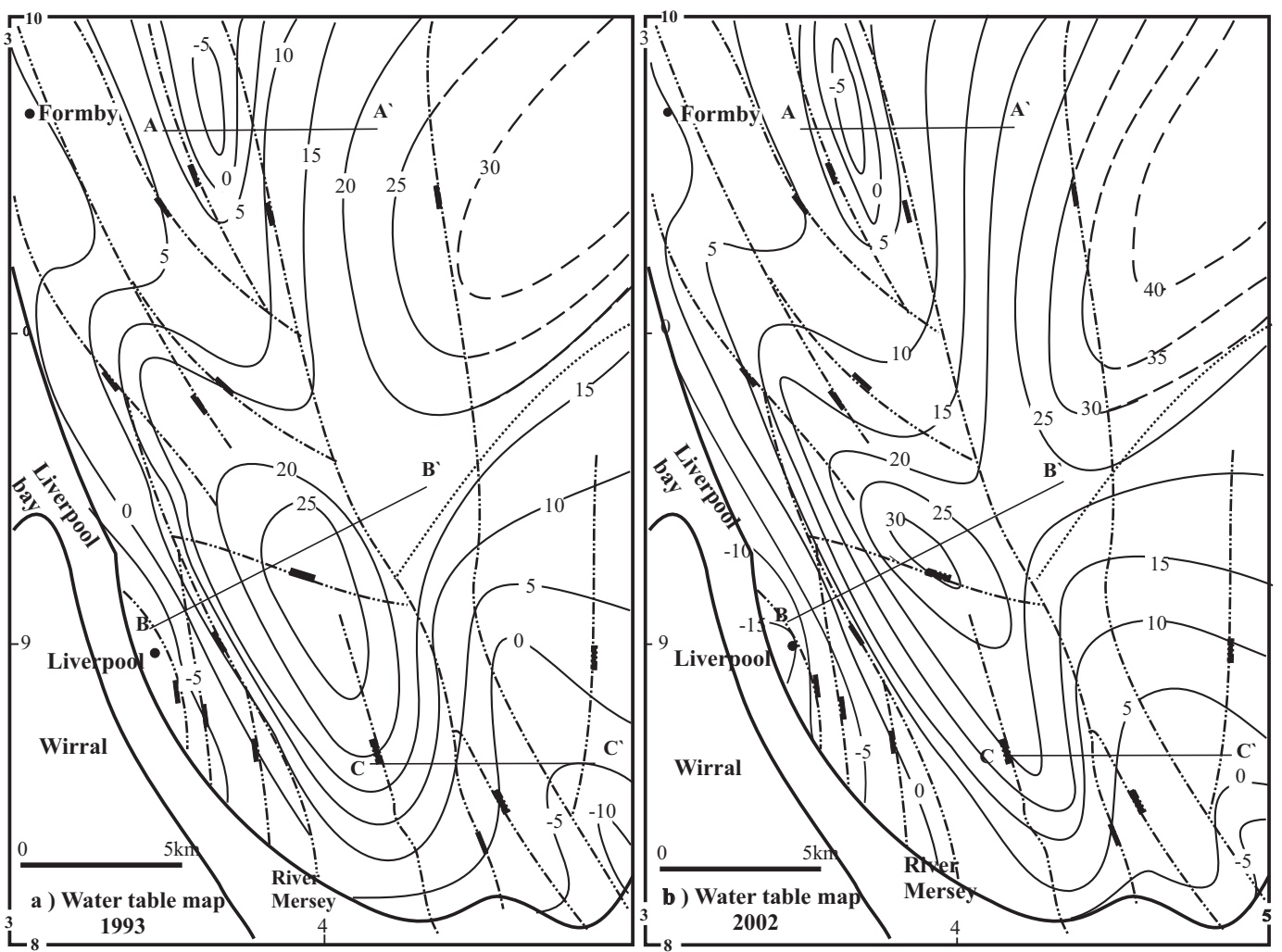

Fig. 3. Water table height in meters relative to the ordinance datum (OD, mean annual sea level); (a) 1993, and (b) 2002. Contouring was based on the assumption employed during the drafting of the published hydrogeological map (Lewis et al., 1989) that the aquifer was a uniform entity with no sub-compartments.

locally intercalated with peat beds. River alluvium of silt, sand and clay has mainly developed in the valley of the River Alt, where the recent estuarine alluvium of sand, silt and mud occurs (University of Birmingham, 1984; Tellam, 1994).

\subsection{Structural geology}

The structural geology of the area is dominated by a variety of faults as represented on published geological maps and cross sections from the British Geological Survey (and its predecessors) and other published work (e.g. Morton, 1866; Wedd et al., 1923; Shackleton, 1953; University of Birmingham, 1984).

Although faults dominate the geological structure from the hydrogeological perspective (Fig. 1), there is also a subtle low amplitude fold with its axis running approximately northeast to southwest. This fold is known as the Knowsley anticline (Fig. 1) and it results in a general, low angle northwest dip over the northern part of the study area and southeast dip in the vicinity of Halewood, Speke and Widnes. There are other small syn- and anti-forms to the north of the Knowsley anticline but they have a very limited effect on the general dip of the strata.

The area is intensively disrupted by numerous large faults. These generally trend north-northwest - south-southeast with some smaller east-west cross faults. The faults are normal with an average $60^{\circ}$ dip (Jones et al., 1938). The throws of these faults vary from a few meters to $>300 \mathrm{~m}$. Examples of faults with large displacements are the Boundary fault, the Croxteth fault and the Eccleston West fault (Tellam, 1983; and Fig. 1). In the Sherwood Sandstone in the north of England, there is a correlation between degree of displacement and fault zone thickness. Fault zones may either be filled with gouge or cataclasite depending on the lithologies on both side of the fault; some of the greatest faults in the area are likely to have potentially impermeable fault zones of $>1 \mathrm{~m}$ thickness (e.g. Beach et al., 1997; Chadwick, 1997; Cowan, 1996; Rowe and Burley, 1997). These major faults (e.g. the Croxteth fault) have been implicated in controlling the occurrence of minor shallow petroleum accumulation to the north of the study area (Kent, 1948; Lees and Taitt, 1945) with the suggestion that the fault zones are effectively impermeable. The faults that seem to cause the greatest geological complexity occur at the boundary between the PermoTraissic and Carboniferous rocks (the Boundary fault, Fig. 1; University of Birmingham, 1984). Minor faults in the Quaternary deposits have been noted by Aitken (1871), Reade (1884) and Taylor (1958). Such faults are syndepositional and have no significant effect on groundwater movement. 

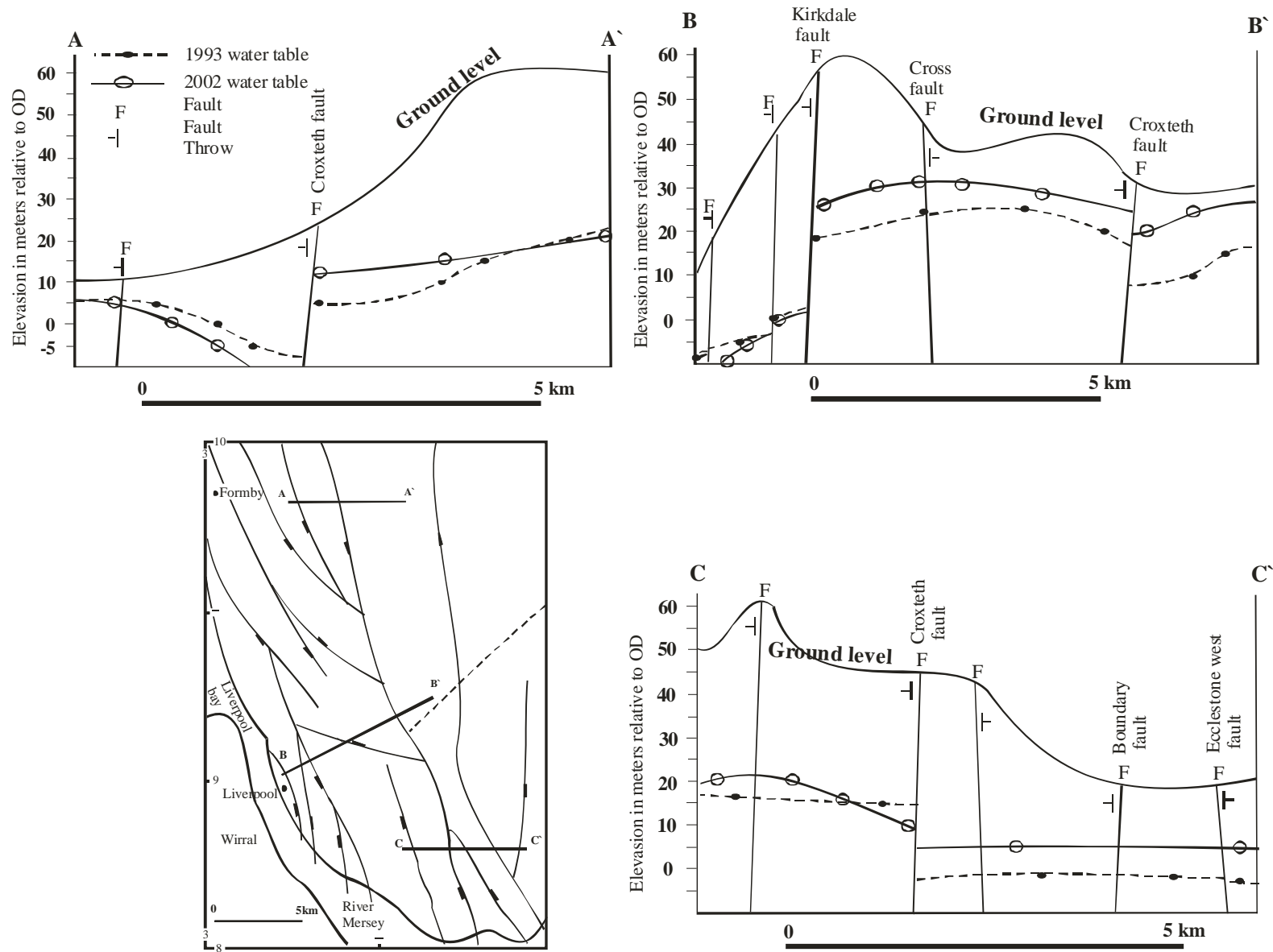

Fig. 4. Schematic cross sections illustrated the variation of the water table height in meters across the faults in years 1993 and 2002 . The locations of the cross sections are shown on the map.

\subsection{Topography}

Although the area has generally low relief, the bedrock topography is locally characterised by narrow, linear lows (up to about $30 \mathrm{~m}$ above sea level) separated by hills that reach up to about $70 \mathrm{~m}$ above sea level (Fig. 2a). These topographic features broadly run northwest to southeast. Travelling further north, the narrow depression opens out to become a wide plane in the northwest area around Formby, the flood plain of the River Alt, with $10 \mathrm{~m}$ maximum elevations above sea level.

\section{Methods}

In this study 75 groundwater head records and 78 groundwater geochemical analyses collected from 70 groundwater wells (Fig. 2b) have been utilised for two discrete year periods $(1993,2002)$. These groundwater head data and geochemical analyses were supplied from the UK Environmental Agency (EA). Head data have been collected from a large number of boreholes in the area for more than 70 years al- though the Environmental Agency has only recently been responsible for collecting and monitoring these data. Head data have been collected at least monthly from most of the monitoring boreholes. The EA staff and the Nottingham EA laboratory followed recommended BSI sampling and analytical methods. Acidity, temperature, conductivity and total salinity were measured immediately after sampling. Previously cleaned sample bottles were rinsed with the groundwater and then filled to the top. Airtight caps were fitted to each bottle prior to transportation to the laboratory. Alkalinity titrations were performed within a few hours of sampling. Ion chromatography was used for the major anions, and atomic absorption and ICP-techniques were used for the major cations. In order to check the quality of the data, all the groundwater geochemical data that were used in this study were assessed for charge balance using Geochemist Workbench. Groundwater analyses with a charge imbalance $>5 \%$ were rejected from the data set.

We concluded that automated geostatistical methods, ideal for gridded data but not suited to the irregular location of sampling points in this study (Fig. 2b), would not be used 

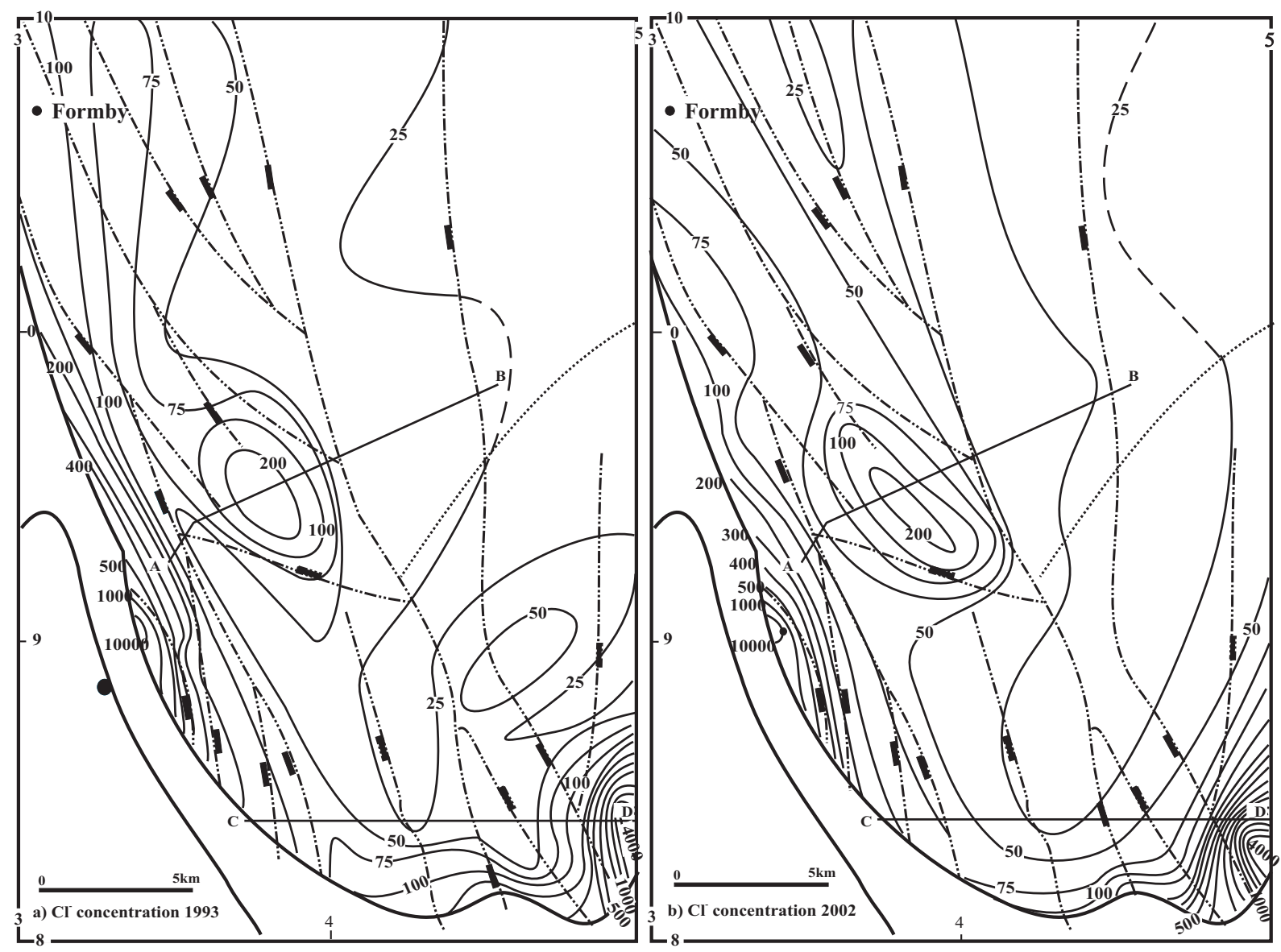

Fig. 5. Aqueous chloride concentrations in mg/L contoured for; (a) 1993 and (b) 2002. Contouring of chloride concentration was based on the assumption that the aquifer is not compartmentalised by the structure elements.

for contouring groundwater head variation and the geochemical data. Instead we have use manual contouring methods to draw maps of water table elevation and groundwater geochemistry.

\section{Results}

\subsection{Groundwater head variation in space and time}

The groundwater head distribution maps from the years 1993 and 2002 have been drawn using the available data from monitoring boreholes. The groundwater head varied from $30 \mathrm{~m}$ above mean annual sea level (ordinance datum; OD) to as much as $15 \mathrm{~m}$ below OD for the years listed above. In the first instance we followed the assumptions implicit in the published regional hydrogeological map (that the aquifer was neither subdivided by faults nor constrained by folds into discrete compartments; Lewis et al., 1989) and freely contoured the groundwater head across the entire area (Fig. 3). It is noteworthy that the water contours drawn in this way have a distinct, though imperfect, NNW-SSE lineation that accords to the main fault pattern (Figs. 1 and 2b).

A number of schematic cross-sections representing topographic and groundwater elevation across some of the main faults in the study area were prepared to trace any effect of the faults on groundwater head height across the fault lines (Fig. 4). These show that there are significant fluctuations of groundwater head height across some of the faults (Fig. 4). Schematic cross-sections illustrate the changes of groundwater head in passing from one side of a fault to another for the years 1993, and 2002. Cross-section A- $\mathrm{A}^{\prime}$, which tracks across the Croxteth fault in the north, shows a very large change of the groundwater head across the main fault, where the small faults have no significant effect on the groundwater head. Cross-section B-B' also traverses the Croxteth fault, Litherland faults and other small faults to the west (Fig. 4). This clearly illustrates the dramatic change of groundwater head across the Croxteth and Kirkdale faults. Furthermore, cross-section $\mathrm{A}-\mathrm{A}^{\prime}$, and $\mathrm{B}-\mathrm{B}^{\prime}$ show that there is no simple relationship between local topographic elevation and groundwater head. These observations of groundwater head 


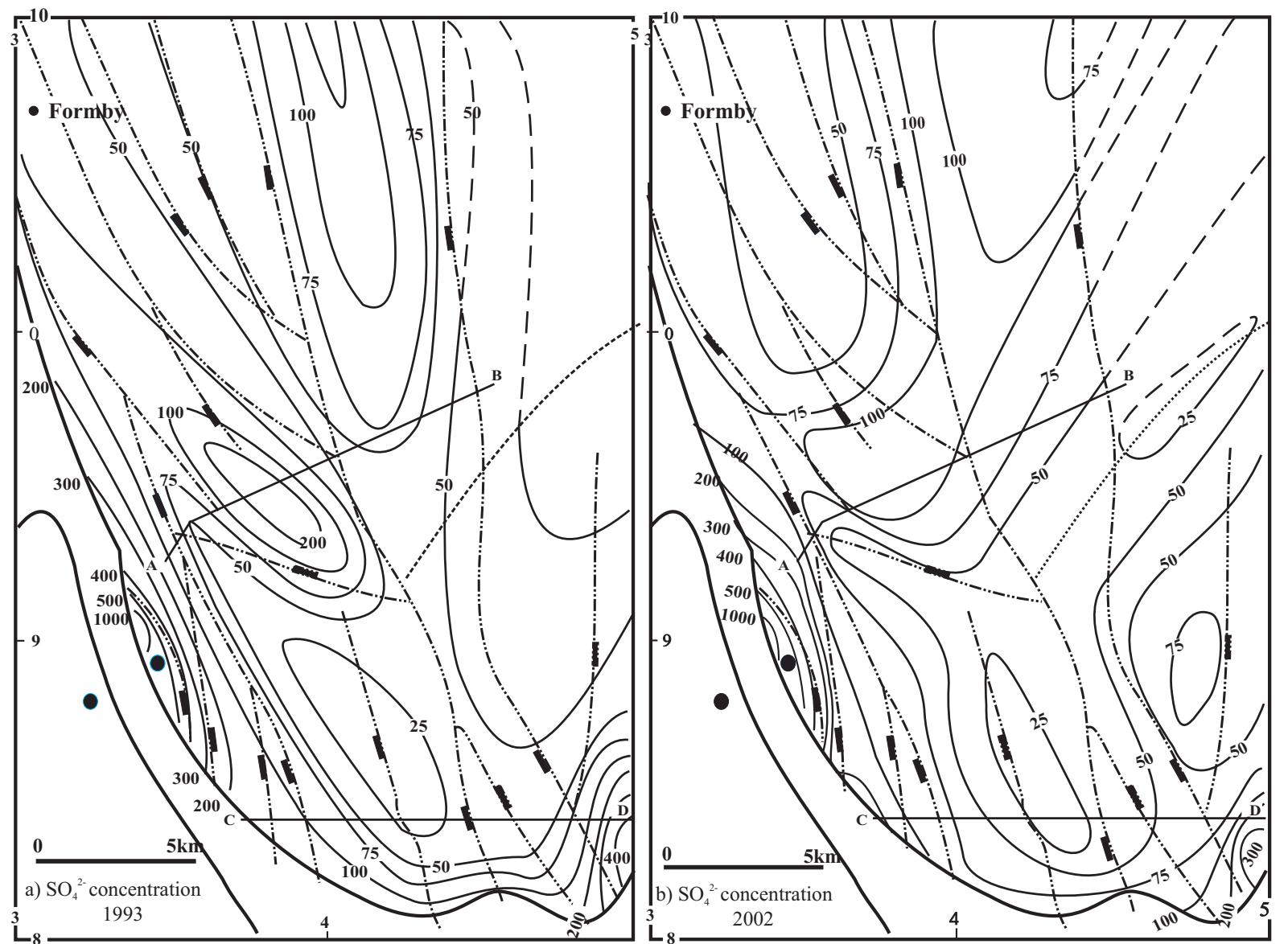

Fig. 6. Aqueous sulphate concentrations in mg/L contoured; (a) 1993 and (b) 2002. Contouring of chloride concentration was based on the assumption that the aquifer is not compartmentalised by the structure elements.

displacement across faults, especially those contrary to the topographic slope, are best interpreted in terms of the faults representing low permeability zones in the aquifer that have limited the movement of groundwater. Cross-section C-C' traverses the Eccleston West, Boundary and Croxteth faults and other small faults in between (Fig. 4). Although the groundwater head follows the topographic elevations, there is a pronounced steep change of groundwater head across the fault lines implying the significant effect of faults on groundwater head in these southern parts of the study area.

\subsection{Groundwater geochemistry}

Chloride, as the geochemically most conservative element in the natural waters, can give direct indication of the degree of mixing between different types of groundwaters and also the existence of seawater intrusion, while sulphate may give a useful insight into other non-conservative processes causing geochemical variations. This paper is not an indepth study of the controls of geochemical variations in this aquifer. Rather, the geochemical data are here used to assess the degree of compartmentalisation.
Distribution maps of the concentrations of aqueous chloride and sulphate (mg/l) from the chosen two years (1993 and 2002) have been prepared (Figs. 5 and 6). These maps were prepared following the initial assumption that the aquifer was neither subdivided by faults nor constrained by folds into discrete compartments and freely contoured the chloride and sulphate concentrations across the entire area. Two cross sections traversing the faults were constructed to illustrate the degree of change in the chloride and sulphate concentrations along the faults (Figs. 7a and b).

As expected for groundwater in temperate climatic regions, chloride concentrations are relatively low $(<100 \mathrm{mg} / \mathrm{l})$ for much of the area for most of the time (Fig. 5). However, there are notable exceptions. The coastal strip near where the Mersey channel is at its narrowest has chloride concentrations in excess of $1000 \mathrm{mg} / \mathrm{l}$ for some of the time and the area is relatively elevated all of the time. Also the southeastern part of the aquifer has locally elevated chloride reaching up to $4000 \mathrm{mg} / \mathrm{l}$. Noteworthy is an area slightly to the west of the centre of the area that has less dramatic chloride concentrations but is also locally elevated above background. The 

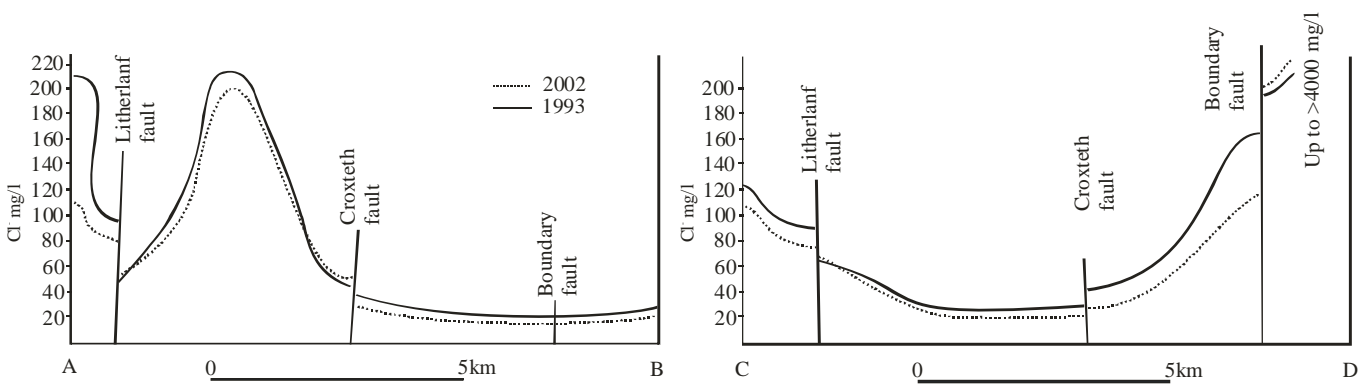

(a)
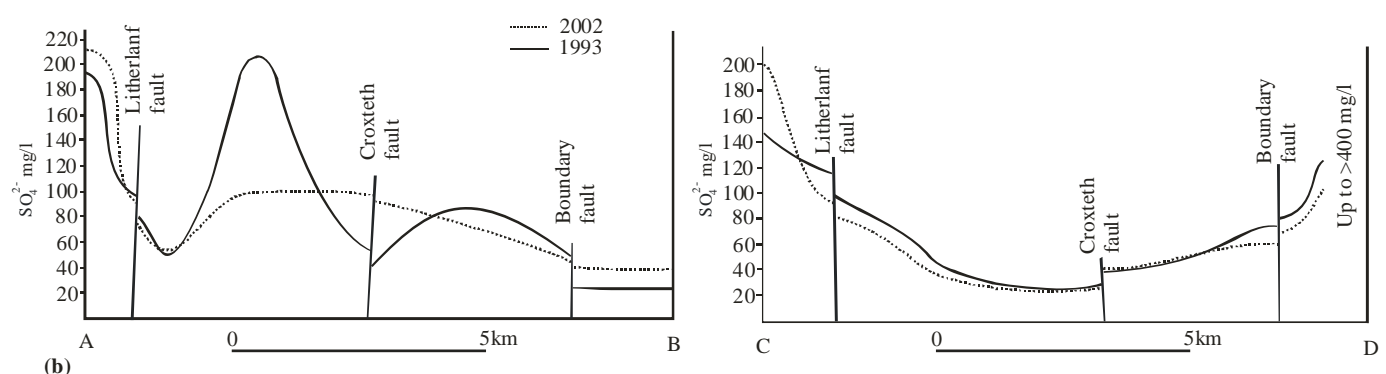

Fig. 7. Schematic cross sections illustrated the variation of the (a) chloride concentration across the faults in years 1993 and 2002 and (b) sulphate concentration across the faults in years 1993 and 2002. The locations of cross-sections showed on the maps (Figs. 6 and 7 , respectively).

elevated groundwater salinity in some of the near-coastal regions is the result of seawater invasion.

Maps of the dissolved sulphate concentrations have some similarities to the chloride maps although they are not exactly the same (Fig. 6). Sulphate is elevated in parts of the coastal strip and just to the west of the centre of the study area but it is also relatively concentrated at the northern edge of the area.

\section{Discussion}

\subsection{Structural geology and groundwater head}

For the two discrete years for which water table height contour maps have been prepared (Fig. 3) it is noteworthy that water table heights do not match topographic variations resulting in anomalously low and high water tables relative to the overlying land surface. The water table reaches maximum elevations in the north eastern part of the study area (more than $30 \mathrm{~m}$ above sea level) and broadly tends to decrease toward the coastline and the Mersey estuary (Fig. 4). This reduction of the water table height towards the coast is not steady across the whole area. There are sudden changes in the water table height over very short distances. In the middle of northern area just west of the Croxteth fault where the water table drops from $>5 \mathrm{~m}$ above sea level to as much as $5 \mathrm{~m}$ below sea level (Fig. 4). Therefore, the Croxteth fault is a fairly well pronounced groundwater barrier. To the mid- dle of the block bounded to the east by the Croxteth fault, water table height does not follow the general reduction towards the coastline and instead rises to more than $25 \mathrm{~m}$ and $30 \mathrm{~m}$ above sea level (Figs. 5a and b, respectively). This elevated groundwater table has a sharp western margin marked by the Kirkdale fault where the groundwater table falls to $10 \mathrm{~m}$ below sea level in the direction of the Mersey estuary (Fig. 4). To the east of Croxteth fault, the water table elevation follows the Knowsley anticline structure (Fig. 1). The fold axis can be recognized as a groundwater divide where the water table falls away from the fold axis. In conclusion, the water table in this part of the aquifer (east of Croxteth fault) is to a fairly large extent unrelated to the regime in the west of this fault. The block to the east of the Croxteth fault can be separated by the anticline axis into northern and southern parts. In the southern part, to the east of the Eccleston West fault a very sharp and dramatic drop of water table height occurs ultimately falling to below sea level (Fig. 4). In general, the variations in the water table contours seem to be controlled by the regional fault and fold lines.

Following the analysis represented in Fig. 4, an alternative contouring scheme was used for groundwater head for the two discrete year periods based on the assumptions that the Croxteth, Ecclestone West and linked Litherland-Kirkdale faults are all low permeability zones strongly limited the groundwater flow. The Knowsley anticline will also act as a local modifier of the groundwater movement and effectively act as a groundwater divide. On this modified basis 

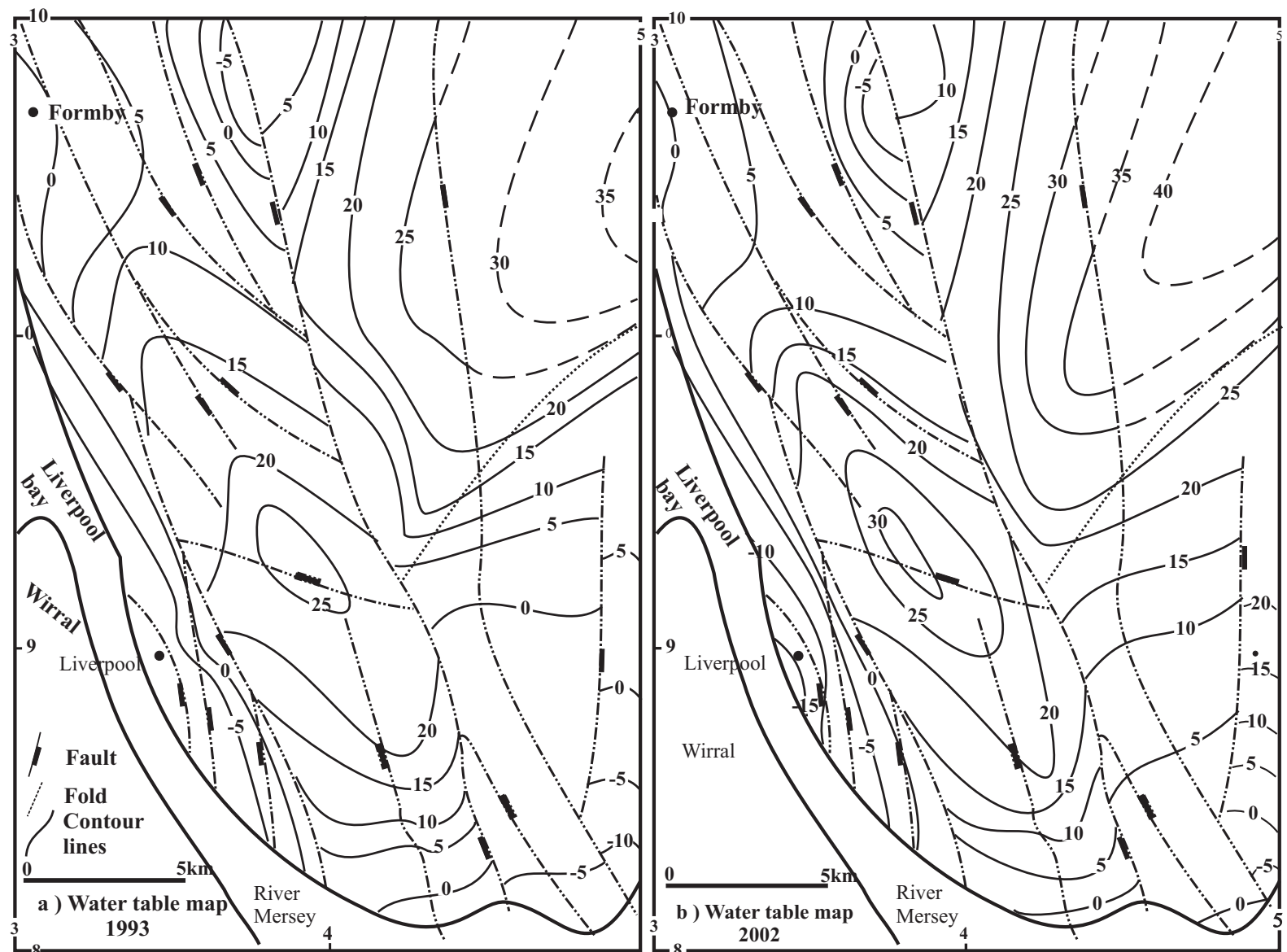

Fig. 8. Water table height in meters relative to the ordinance datum (OD, mean annual sea level); (a) 1993 and (b) 2002. The maps were prepared using the same data as Fig. 3 but, in contrast to Lewis et al. (1989), contouring was based on the assumption that the aquifer is compartmentalised by the Boundary, Croxteth, Litherland-Kirkdale and Ecclestone West faults and the Knowsley anticline (see Fig. 4).

the groundwater head map was tentatively re-contoured for the two years assuming the aquifer was compartmentalised by these geological structures (Fig. 8). Figure 8 can be compared to Fig. 3 to reveal the consequence of the recognition of the low hydraulic conductivity fault zones. The head contours are distinctly interrupted in the vicinities of the Croxteth, Ecclestone West and linked Litherland-Kirkdale faults.

The previous discussion shows that at least some of the faults that dissect the regional Permo-Triassic Sherwood Sandstone aquifer and represented on the geological map (Fig. 1) could be low permeability zones that have limited the movement of groundwater. The close similarity in the hydrogeological properties of the Permo-Triassic sandstone formations suggest that low permeability characteristics of fault zones are mainly due to the low permeability of the filling materials. Note that the Sherwood Sandstone aquifer is hugely dominated by fine to coarse grained sandstones. Fault movement within the Sherwood Sandstone aquifer is unlikely to result in the dominant juxtaposition of intraformational mudstones and sandstones. Fault zones in the Sher- wood Sandstone will be dominated by cataclasis, grain size diminution and possibly cementation (Beach et al., 1997; Chadwick, 1997; Cowan, 1996; Rowe and Burley, 1997). However, in the extreme east of the area, the Boundary Fault, with its great displacement $(>300 \mathrm{~m})$, juxtaposes the low permeability, mudstone-rich Upper Carboniferous against the Sherwood Sandstone, therefore it has probably got the lowest permeability values (Moor, 1902; Tellam, 1983) and so will have had greatest effect on groundwater movement.

On the basis of fault distribution patterns and water table elevations, the aquifer could be subdivided into several hydrogeological sub-basins with boundaries defined largely by faults. However, the subtle regional fold (Fig. 1) may also influence groundwater movement patterns with groundwater flow being away from the antiform axis. These sub-basins (Fig. 8) are thus defined by the fold axis and the most significant faults (those that have affected water table elevation most extensively and those with the most significant impacts on geological outcrop patterns. Hydrogeological sub-basin 1 (B1) occupies the area to the north of the Knowsley anticline 

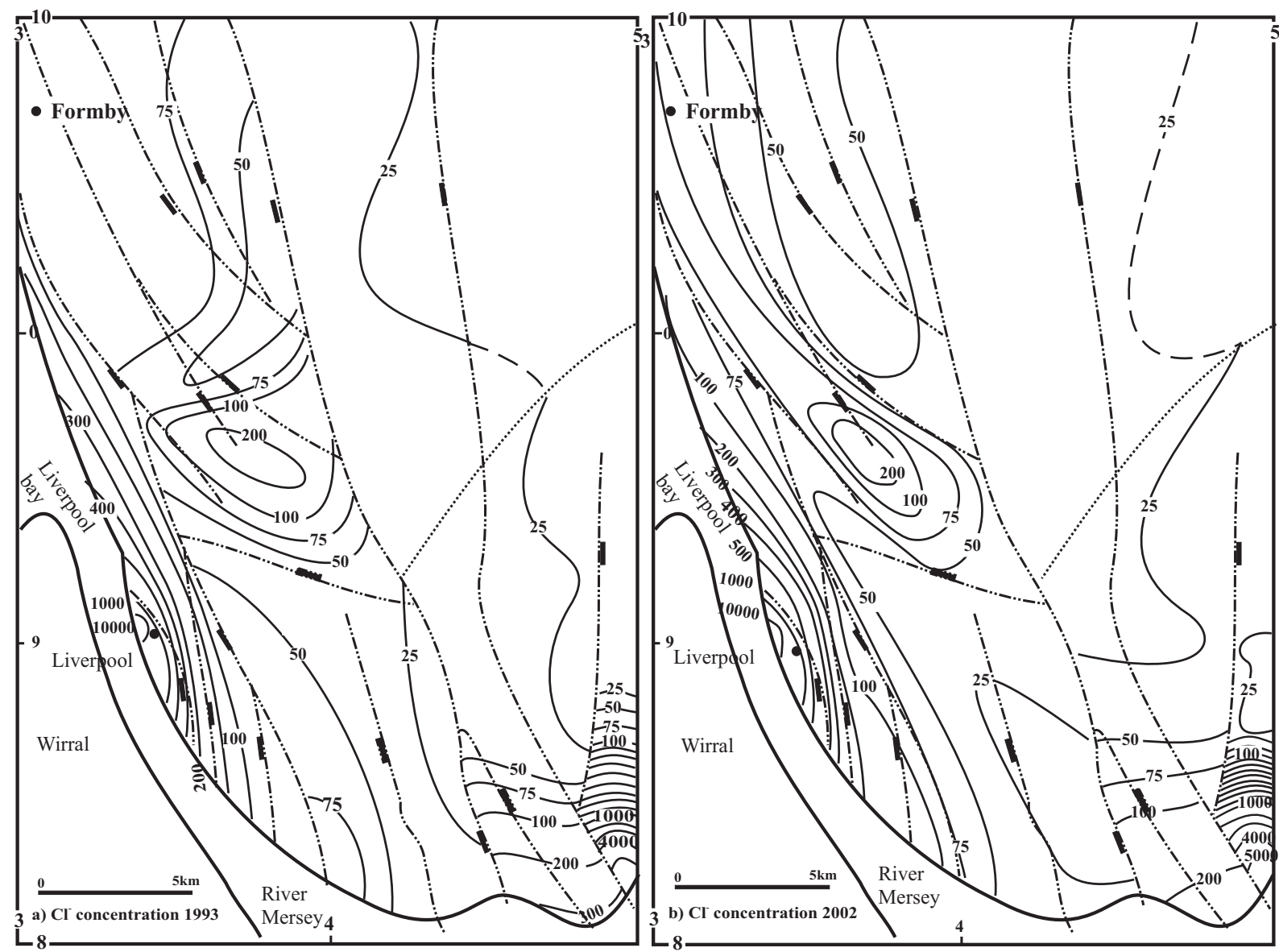

Fig. 9. Aqueous chloride concentration in $\mathrm{mg} / \mathrm{L}$ contoured for (a) 1993 and (b) 2002. The maps were prepared using the same data as Fig. 5 but, contouring was based on the assumption that the aquifer is compartmentalised by the Boundary, Croxteth, Litherland-Kirkdale and Ecclestone West faults and the Knowsley anticline.

and is bounded by the Croxteth fault in the west and Boundary fault in the east. Sub-basin B2 lies to the south of the Knowsley anticline and is limited in the west by the southern extension of the Croxteth fault and the Carboniferous sediments and Ecclestone West fault in the north and east. Subbasin B3 lies to the east of the Eccleston West fault. Subbasin B4 lies between the Croxteth fault to the east and the Litherland-Kirkdale faults to the west. Sub-basin B5 has its eastern margin defined by the linked Litherland and Kirkdale faults. At this stage, the interpretation is somewhat tentative being based solely on water table elevations in relation to topography and fault patterns, structural geology (faults and fold) and outcrop patterns. Independent geochemical data will now be employed to help ascertain the validity of the interpretation of compartmentalisation.

\subsection{Sub-basin definition and groundwater geochemistry}

The previous analysis included no water geochemical evidence for the compartmentalisation of the aquifer into discrete sub-basins. Geochemical data should be capable of assessing the plausibility of the tentatively assigned sub-basins.
The initial contour maps of chloride and sulphate concentration (Figs. 5 and 6) have been redrawn and re-contoured (Figs. 9 and 10) using the new concept that the Croxteth, Ecclestone West and linked Litherland-Kirkdale faults limit water movement and that the Knowsley anticline also acted as a barrier to movement (thus compare Figs. 9 and 10 to Figs. 5 and 6). Note that the Boundary fault is the effective eastern limit of the aquifer as it brings aquiclude Carboniferous rocks against Permo-Triassic aquifer (Fig. 1).

Chloride distribution maps for the two years (Figs. 5 and 9) reveal that the areas of very high chloride concentration (that $>1000 \mathrm{mg} / \mathrm{l}$ ) predominantly lies very close to the Mersey Estuary or the open sea. In the western part, the contours of chloride concentration run approximately NNW-SSE and are parallel to, and bounded to the east by, the linked Litherland and Kirkdale faults. This seems to broadly concur with the definition of sub-basin B5. However, the very highest chloride concentrations in this area are constrained to an area west of a small fault near the coast. This is also the area that has some of the lowest water table elevations (up to $15 \mathrm{~m}$ below sea level). This area is conceivably a 

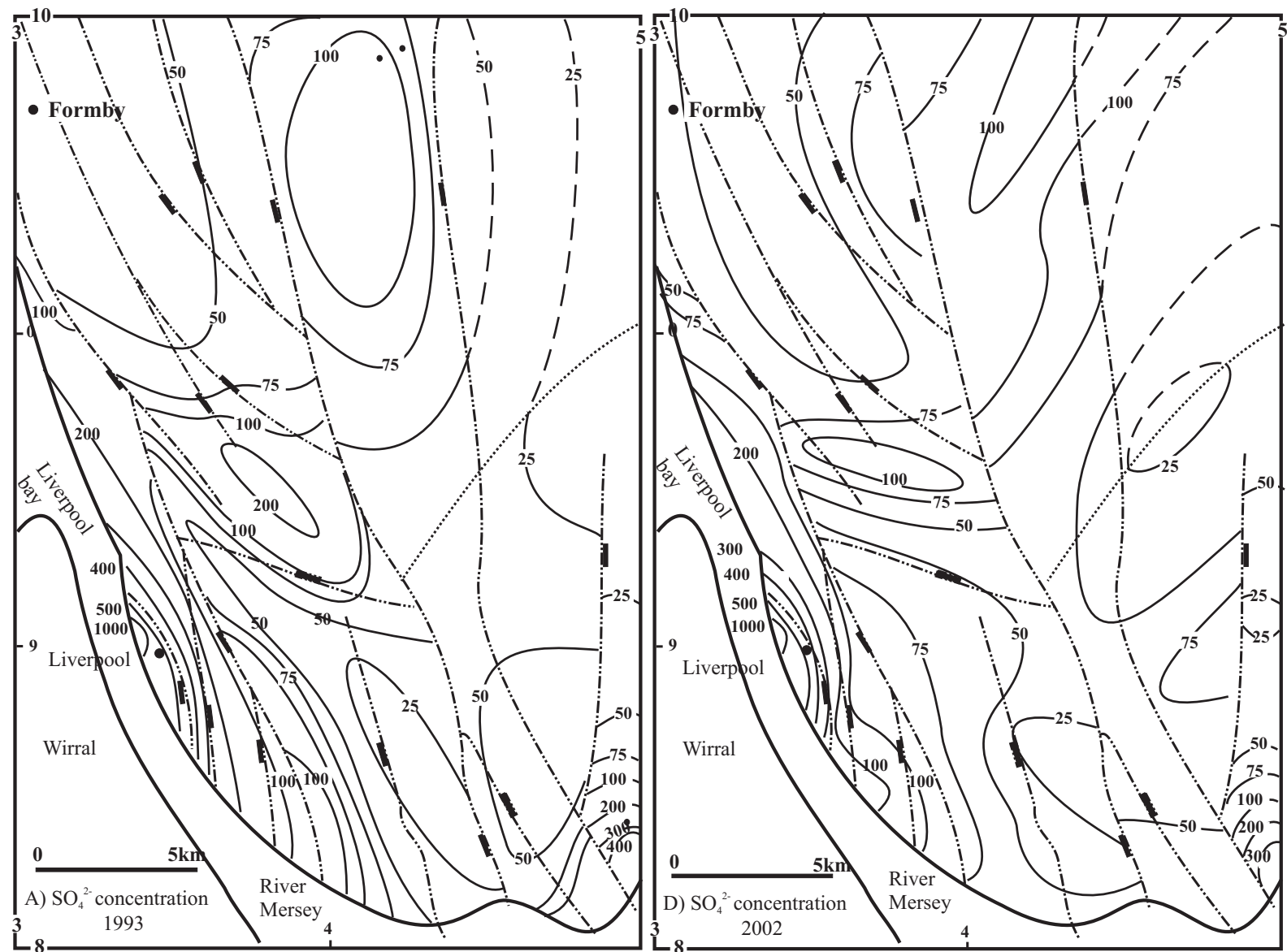

Fig. 10. Aqueous sulphate concentration in $\mathrm{mg} / \mathrm{L}$ contoured for (a) 1993 and (b) 2002. The maps were prepared using the same data as Fig. 6, but contouring was based on the assumption that the aquifer is compartmentalised by the Boundary, Croxteth, Litherland-Kirkdale and Ecclestone West faults and the Knowsley anticline.

separate sub-basin (B6) and is likely to be defined by the fault that runs west of, and sub-parallel to, the linked Litherland and Kirkdale faults, which is known as the Kingsway fault (Fig. 2b). This fault was considered previously by (Barker, 1996) to be a sealed fault that limits eastwards seawater invasion. In the extreme southeast of the area (near Widnes), the elevated chloride concentrations in the groundwater (locally $>4000 \mathrm{mg} / \mathrm{l})$ seem to be sharply defined. This represents the B3 sub-basin. It is possible that the locally elevated chloride concentrations are limited to the west by the Ecclestone West fault and Boundary fault (Figs. 5 and 9). Away from the coast, there are some locally elevated chloride concentration values not easily correlated with the values in neighbouring areas. In sub-basin B4 there is an area with chloride concentrations $>200 \mathrm{mg} / \mathrm{l}$ that is anomalous with respect to the remainder of the sub-basin. The Croxteth fault seems to define differences in chloride concentration between the tentatively assigned sub-basins B1, B2 and B4, where the LitherlandKirkdale faults define the differences in chloride concentration between the tentatively assigned sub-basins B5 and B4.
The sulphate concentration contour maps have some similarities with chloride concentration contour maps (Figs. 6 and 10). As for chloride, one of the areas with the highest sulphate concentrations lie close to the Mersey River bounded by the linked Litherland and Kirkdale faults although sulphate concentrations $\cong 1000 \mathrm{mg} / \mathrm{l}$ only occur very close to the coast supporting the existence of a separate sub-basin in B5, here defined as B6 using the water geochemistry data (Figs. 6 and 10). Based on the sulphate as well as the chloride concentration data, in the extreme southeast of the area, subbasin B3 is defined to the west by the Eccleston West fault and Boundary fault. To the middle of B4 is an area of anomalously high sulphate concentration $(>200 \mathrm{mg} / \mathrm{l}$; Figs. 6 and $10)$. In the north of the study area, to the east of the Croxteth fault the sulphate concentration locally rises to $>100 \mathrm{mg} / \mathrm{l}$ while to the west of the Croxteth fault the sulphate concentration fall to $<50 \mathrm{mg} / \mathrm{l}$ (Figs. 6 and 10). This seems to confirm that the Croxteth fault is an effective seal between discrete compartments (B1, B2 and B4). The chloride and sulphate concentration maps seem to support the Knowsley anticline 
as a feature that effectively separates sub-basins B1 and B2 (Figs. 6 and 10).

The maps of water geochemistry broadly support the notion of sub-basins although the initial sub-division of the area based on water table and the occurrence of structural geological features is not wholly confirmed. Initially assigned sub-basins B1to B5 seem to be broadly robust. An extra subbasin to the western edge of B5 may be operative and has been labelled B6.

The newly identified compartments to the aquifer are delineated in Fig. 11. In this figure the aquifer is divided into areas (B1 to B6) that the water table head and geochemical data have identified. The compartments (B1 to B6) are seemingly isolated from each other. This has significant implications for recharge patterns, pollution movement and public water supply issues.

The compartmentalisation of the aquifer based on contoured maps of water table height (Fig. 8) and geochemistry (Figs. 9 and 10) can be tested further by examining individual and averaged geochemical characteristics of each of these newly defined aquifer compartments. Although the faults are not the main reason for the geochemical variation between sub-basins, they can plausibly highlight any differences that exist. The use of averaged geochemical parameters can give an overall view of any geochemical differences. Illustrations employing all the geochemical data are not particularly helpful since the figure is very crowded and is not easy to interpret. These averaged data have been added to binary crossplots (Fig. 12). The average geochemical parameters and standard deviation cross-plots of each sub-basin (Fig. 12) indicate that the geochemical composition of groundwater in sub-basins B1, B2 and B4 are fairly similar but sub-basins B3, B5 and B6 are all quite different and seemingly unrelated either to one another or to sub-basins B1, B2 and B4. The broadly similar geochemical compositions of waters in sub-basins B1, B2 and B4 could be a result of similar geochemical processes in these parts of the aquifer leading to similar evolutionary pathways. The wide inland extension of B3 sub-basin (Fig. 11) seems to result in a high degree of mixing between saline and fresh groundwaters leading to the wide range of geochemical parameters (as reflected by the magnitude of the standard deviation values) in this sub-basin. In contrast, B6 sub-basin where the tendency for mixing between saline- and fresh-groundwater is limited by the sealed fault (Kingsway fault, Fig. 11) the variation range of geochemical parameters is very limited (Fig. 12). The geochemical evolution of groundwater in B5 is seemingly unique and is not particularly related to any other sub-basin.

Sub-basin B4 has a small degree of overlap with B1 and B2 (Fig. 12a) possibly suggesting that there is limited water movement across the Croxteth fault. The notion that B4 is discrete from B1 and B2 is largely supported by the geochemical data. B4 has moderately elevated sulphate concentrations relative to $\mathrm{B} 2$ and moderately high magnesium concentration relative to $\mathrm{B} 1$ and $\mathrm{B} 2$ (Fig. 12). There is some de-

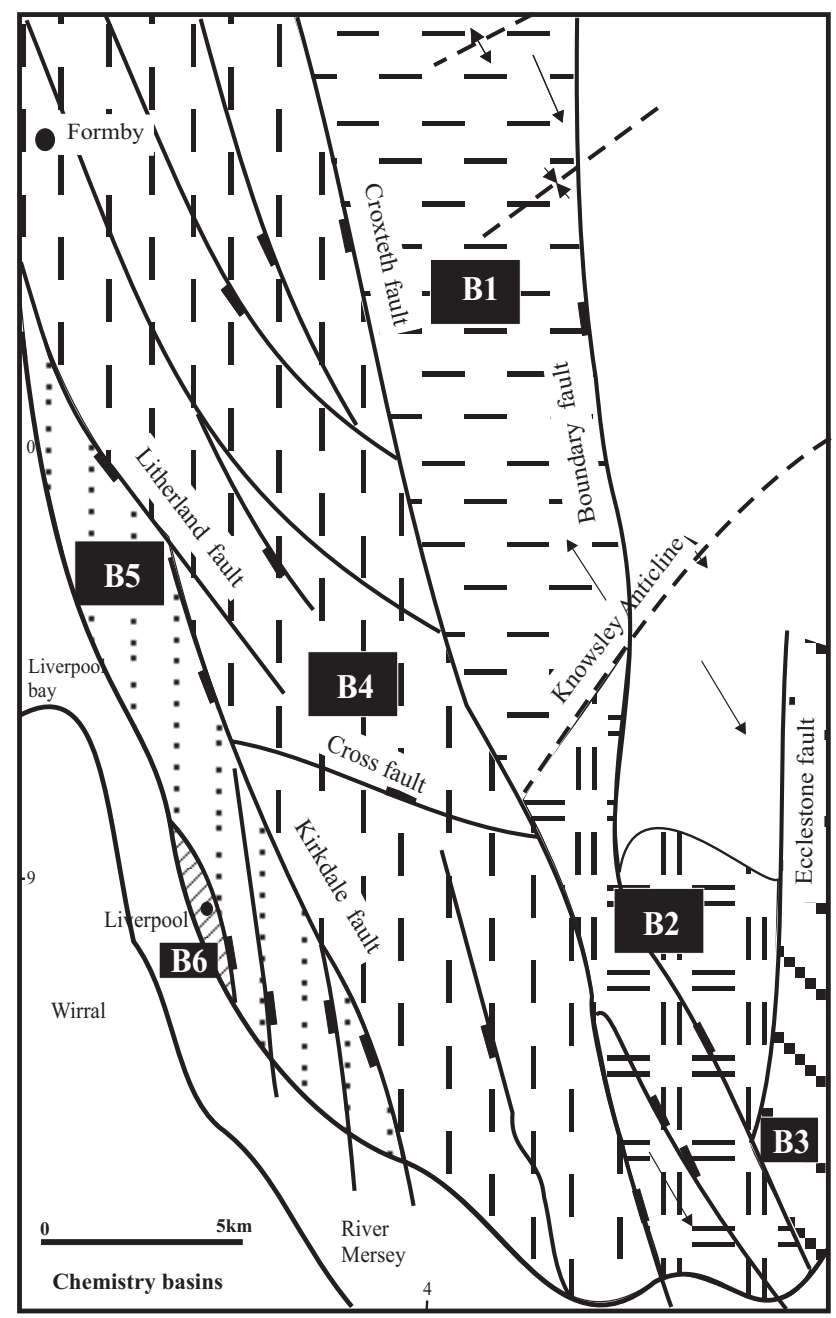

Fig. 11. Suggested division of hydrogeological sub-basins based on water table height and water geochemical data.

gree of geochemical overlap between groundwater samples from sub-basins B1 and B2 although there is a significant difference between the cross-plotted data (Fig. 12) suggesting that these sub-basins are indeed discrete aquifers. B1 has very low chloride and moderately low sulphate whereas B2 has moderately low chloride and very low sulphate. In order to differentiate between the geochemical evolution of the groundwaters in B1, B2 and B4 average sulphate and chloride cross-plots have been developed (Fig. 13). This figure indicates that, the main recharge of the groundwater in these three sub-basins seems to be the same, however, the groundwater evolution in each sub-basin follows a different direction. In B1, both parameters are inversely correlated where the sulphate concentration increases in the same way as chloride concentration. In B2 there is no correlation between the two parameters. High chloride anomalies are recorded only in the samples close to the Mersey River in B2 (Fig. 11). In B4 sulphate and chloride concentrations are 

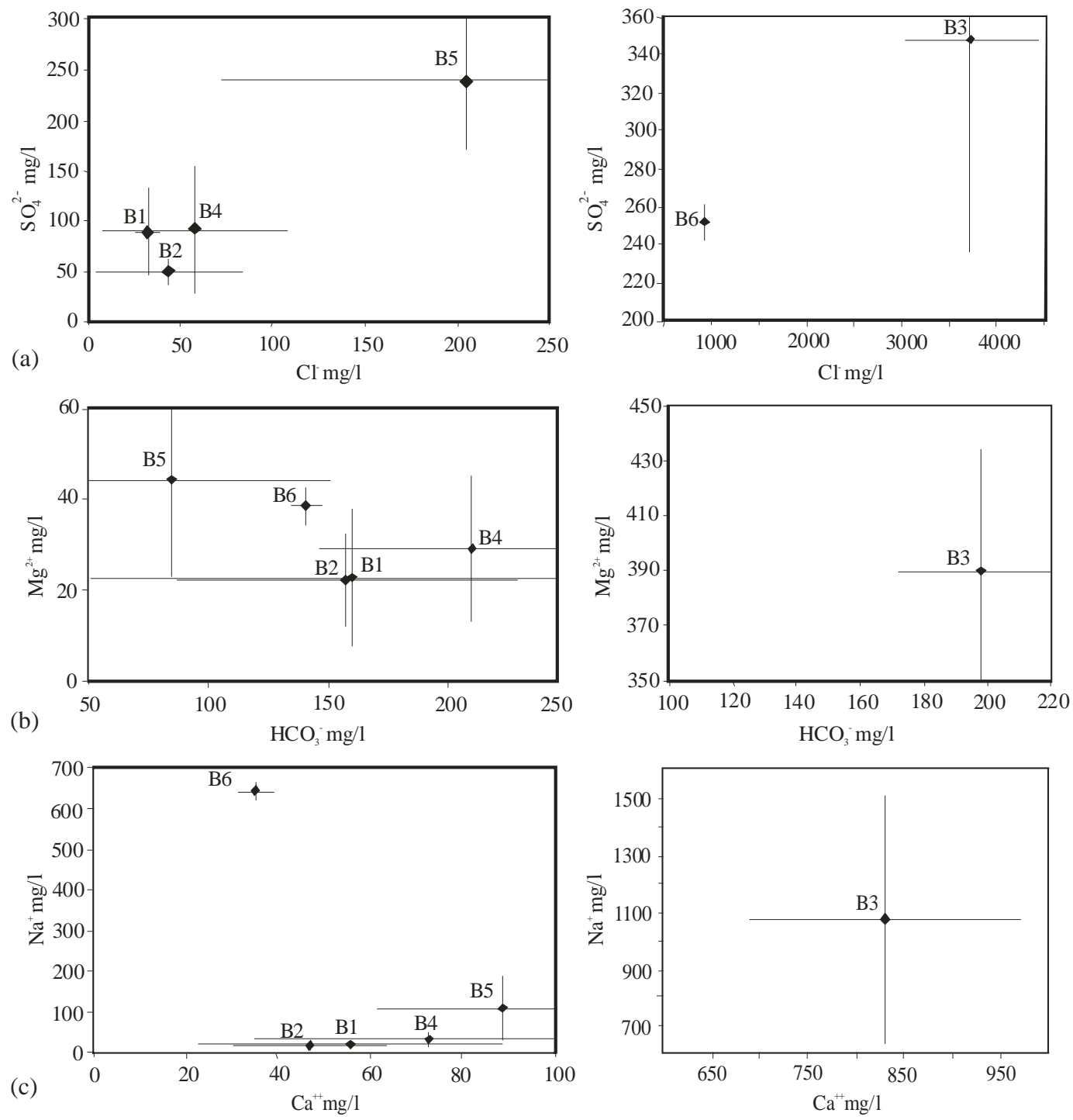

Fig. 12. Geochemical cross-plots; (a) average chloride concentrations vs. average sulphate concentrations (b) average magnesium concentrations vs. average bicarbonate concentrations, (c) average sodium concentrations vs. average calcium concentrations. Note, for simplification the very high chloride concentration samples $(>4000 \mathrm{mg} / \mathrm{l})$ in B6 were excluded in this graph as this sub-basin is separated from the others by the Kingsway fault.

directly correlated which may be a result of them having a related set of controls in this sub-basin.

The similarity in the overall groundwater geochemistry in compartments B1, B2 and B4 (Figs. 12 and 13), with their own localised head variations, seems to support the conclusion that faults are zones of low hydraulic conductivity. If there had been no barriers, then the regional movement of water in all three zones would likely have resulted in regional geochemical evolution patterns. Instead, the groundwater has broadly similar composition in all three discrete compartments and there has certainly not been regional scale change resulting in differences along regional flow paths.
Therefore the degree of compartmentalisation of the major aquifer in the area tested by the groundwater heads is broadly supported well by the variation in the geochemical composition of groundwater.

\section{Significance}

It has been known that petroleum accumulations are commonly divided into discrete fluid compartments for a number of years. The data typically used to assess the degree of compartmentalisation include fluid pressure data, fluid contact (e.g. oil-water) depths, oil geochemistry, gas geochemistry, 
associated water geochemistry, and the physical properties of petroleum (Smalley and England, 1992, 1994; Smalley et al., 1995). By analogy we have here used water table height variations (equivalent to fluid pressure variations and fluid contact depths in oil fields) and water geochemistry data (equivalent to petroleum geochemistry data). This approach has proved to be very effective in determining the degree of compartmentalisation in a near-surface aquifer. These data are typically available from aquifers in developed regions and the approach could be widely applied with only minor extra expense.

The compartmentalisation in the Sherwood sandstone aquifer is primarily a result of the occurrence of a series of major faults that traverse the sandstone-dominated bedrock. The faults have vertical displacements of up to several hundred meters and probably have meter-thick zones composed of low permeability fault gouge and cataclasite resulting from the ancient movements of the faults (Beach et al., 1997; Chadwick, 1997). Faults are also commonly implicated in the lateral compartmentalisation of oil fields although vertical compartmentalisation in oil fields can also be the result of stratification of permeable and impermeable sedimentary units, growth of diagenetically-cemented layers etc.

Why does the compartmentalisation of this coastal aquifer matter? The water table close to the coastline is, in some locations, $10 \mathrm{~m}$ below sea level (as a result of anthropogenic activities). However, the landward movement of seawater in the aquifer has been locally limited by faults. Where the faults are sub-parallel to the coastline the landward invasion is spatially restricted to the near-shore region of the aquifer. In stark contrast, where the faults are approximately perpendicular to the coastline, the landward invasion of seawater is more extensive since there is nothing preventing the advance into the coastal aquifer. Managing groundwater resources is done most effectively with knowledge of compartmentalisation and its controls. These would enable prediction of groundwater movements. Adopting the notion that the aquifer is merely a "tank of sand" (as is implicit in the regional hydrogeological map; Lewis et al., 1989) would lead to a whole host of errors in predicting occurrence and extent of saline intrusion.

The region in question has relatively high ground to the east where the Sherwood sandstone sub-crop could potentially be a site of active recharge to the entire aquifer. The existence of groundwater compartments due to NNW-SSE oriented sealing faults suggests that this scenario is perhaps unlikely. The NNW-SSE sealing faults will restrict E-W recharge. Recharge of the aquifer is thus most likely via vertical percolation of rainfall. This is supported by the occurrence of a water table high in the SW of the area (under a local topographic high) and a long way from the relatively high ground in the east.

One of the practical implications for the occurrence of compartmentalisation is that any lateral spread of contaminants due to poor environmental protection will be

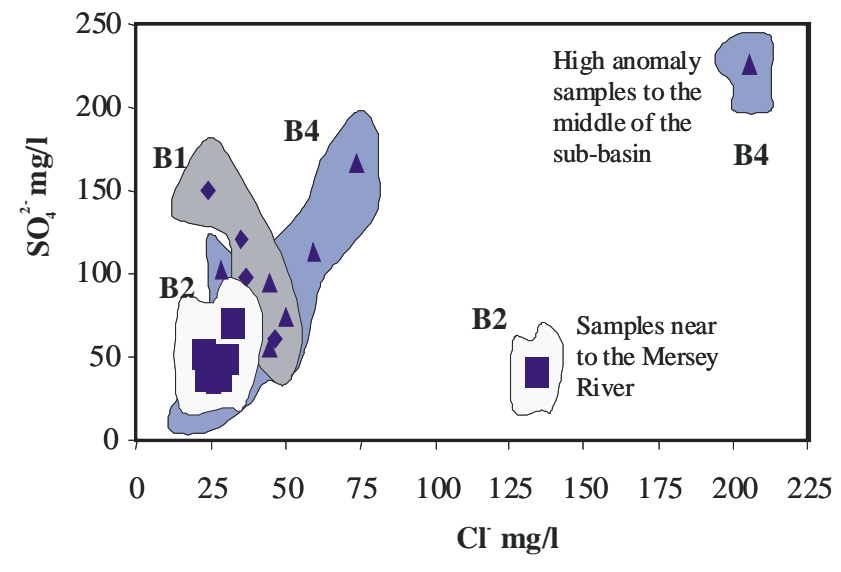

Fig. 13. The cross plots of concentrations of sulphate versus chloride for the B1, B2 and B4 sub-basins samples.

spatially restricted to the local compartment. Point-source pollution is unlikely to spread to the entire aquifer.

\section{Conclusions}

1. Analysis of water table height variations and groundwater geochemistry reveals different sub-basins, or compartments, within the Triassic Sherwood Sandstone aquifer in the Liverpool area in the UK.

2. NNW-SSE oriented geological faults, with vertical displacements of up to $300 \mathrm{~m}$, traverse the Triassic and represent the vertical margins of discrete compartments within the aquifer.

3. The combination of fluid pressure gradients (as represented by water table height), water geochemistry data and an appreciation of the dominant geological structures in an aquifer (e.g. major faults) proved effective in defining the degree of compartmentalisation in the aquifer.

4. Lateral influx of seawater is limited by the occurrence of low hydraulic conductivity faults running sub-parallel to the coastline in the west of the aquifer. These faults are perpendicular to the coastline in the south of the aquifer and have permitted more extensive landward invasion of seawater.

5. Geochemical data show that mixing of groundwater between different compartments is limited by NNW-SSE trending faults. This reveals that lateral recharge of the aquifer from higher ground in the east will be limited. Recharge must be by vertical percolation thus spatially limiting the extent of any groundwater contamination by anthropogenic activities. 
Acknowledgements. The work was funded through a $\mathrm{PhD}$ award from the Egyptian Education and Cultural Bureau, London. The Department of Earth \& Ocean Sciences at the University of Liverpool is duly acknowledged. The authors would like to thank the Environmental Agency staff J. Ingram and D. Billington for supplying us with the data set used in this study.

Edited by: J. Carrera

\section{References}

Aitken, J.: On faults in drift at Stockport, Cheshire. Transactions of the Manchester, Geological Society, 10, 46-49, 1871.

Barker, A. P.: Isotopic studies of groundwater diagenesis. PhD Thesis, Leeds University, 139 p., 1996.

Beach, A., Brown, J. J., Welbon, A. L., McCallum, J. E., Brockbank, P., and Knott, S.: Characteristics of fault zones in sandstones from NW England: application to transmissibility, in: Petroleum geology of the Irish Sea and adjacent areas, edited by: Meadows, N. S., Trueblood, S. P., Hardman, M., and Cowan, G., Special Publication of the Geological Society, 124, 315-324, 1997.

Chadwick, R. A.: Fault analysis of the Cheshire Basin, NW England, in: Petroleum geology of the Irish Sea and adjacent areas, edited by: Meadows, N. S., Trueblood, S. P., Hardman, M., and Cowan, G., Special Publication of the Geological Society, 124, 297-313, 1997.

Cowan, G.: The development of the North Morecambe gas field, East Irish Sea, UK, Petroleum Geoscience, 2, 43-52, 1996.

Hull, E.: The geology of the country around Prescot, Lancashire, 3rd Ed. Mem. Geol. Surv. Gt. Brit., 1882.

Jones, R. C. B., Tonks, L. H., and Wright, W. B.: Wigan District, Mem. Geol. Surv. Gt. Brit., 1938.

Kent, P. E.: A deep borehole at Formby, Lancashire, Geological Magazine, 85, 22-35, 1948.

Land, D. R.: Hydrogeology of the southern part of the northwest region, Geol. Surv. on file report, 1964.

Lees, G. and Taitt, A. H.: The geological results of the search for oilfields in Great Britain, Quart. J. Geological Soc., 101, 255317, 1945.

Lewis, M. A., Doorgakant, P., Lawrence, A. M., Monkhous, R. A., (section Leader), with the assistance of Riden, J. of Welsh Water and Eggboro, M. D., and other staff of North West Water: Hydrogeological map of Clwyd and the Cheshire basin, British Geological Survey, 1989.

Morton, G. H.: On the position of the wells for the supply of water in the neighbourhood, Proc. Liverpool Geological Soc., 8, 241267, 1866.

Moore, C. C.: A study of the volume composition of rocks and its importance to the geologist, Proc. Liverpool Geological Soc., 9, 129-162, 1902.

Reade, T. M.: A section of the Trias at Vyrnwy Street Everton displaying evidence of lateral pressure, Proc. Liverpool Geological Soc., 5, 158-159, 1884.
Reilly, T. E. and Pollock, D. W.: Factors affecting areas controlling recharge to wells in shallow aquifers, U.S. Geological Survey Water Supply Paper 2412, 1993.

Rowe, J. and Burley, S. D.: Faulting and porosity modification in the Sherwood Sandstone at Alderley Edge, northeastern Cheshire: an exhumed example of fault-related diagenesis, in: Petroleum geology of the Irish Sea and adjacent areas, edited by: Meadows, N. S., Trueblood, S. P., Hardman, M., and Cowan, G., Special Publication of the Geological Society, 124, 315-324, 1997.

Shackleton, R. M.: Geology in a scientific study of Merseyside, edited by: W. Smith, Published for Brit. Assoc. by Uni. Press of Liverpool, 1953.

Smalley, P. C. and England, W. A.: Assessing reservoir compartmentalization during field appraisal: how geochemistry can help, SPE 25005, 1992.

Smalley, P. C. and England, W. A.: Reservoir compartmentalization assessed with fluid compositional data, SPE Reservoir Engineering, 175-180, 1994.

Smalley, P. C., Dodd, T. A., Stockden, I. L., Raheim, A., and Mearns, E. W.: Compositional heterogeneities in oilfield formation water: identifying them, using them, in: The geochemistry of reservoirs, edited by: Cubbitt, J. M. and England, W. A., Special Publication of the Geological Society, 86, 59-69, 1995.

Stephenson, R.: Report on the supply of water to the town of Liverpool, Report to the Water Committee of Liverpool Town Council, 1850.

Taylor, B. J.: Report on underground water resources: the PermoTriassic area of south Lancashire, Unpub. Rep., Geol. Surv. Manchr. Office, 1957.

Taylor, B. J.: Cemented shear-planes in the Pleistocene middle sands of Lancashire and Cheshire, Proc. Yorkshire Geological Soc., 31, 359-365, 1958.

Tellam, J. H.: Hydrochemical studies of the Lower Mersey basin Permo-Triassic sandstone aquifer system. PhD Thesis, Birmingham University, 1983.

Tellam, J. H.: The groundwater chemistry of the Lower Mersey Basin Permo-Triassic sandstone aquifer system, UK: 1980 and Pre-industrialization-urbanisation, J. Hydrol., 161, 287-325, 1994.

Tellam, J. H., Lloyd, J. W., and Walters, M.: The morphology of a saline groundwater body: its investigation, description and possible explanation, J. Hydrol., 83, 1-21, 1986.

University of Birmingham: Lower Mersey Basin Saline Groundwater Study, final report to the North West Water Authority by the University of Birmingham, Summary report, 1981.

University of Birmingham: North Mersey Basin Saline Groundwater Study, final report to the North West Water Authority by the University of Birmingham, Summary report, 1984.

Wedd, G. B., Smith, B., Simmons, W. C., and Wary, D. A.: The geology of Liverpool, Mem. Geol. Surv. Eng. and Wales, 1923. 